\title{
Development of an Industrial Process Based on the Groebke- Blackburn-Bienaymé Multicomponent Reaction: Efficient Preparation of 3-Aminoimidazo[1,2-a]pyrazines
}

\author{
Markus Baenziger \\ Estelle Durantie*1 \\ Christian Mathes \\ Novartis Pharma AG, Postfach, 4002 Basel, Switzerland \\ estelle.durantie@unifr.ch \\ markus.baenziger@novartis.com \\ christian.mathes@novartis.com
}
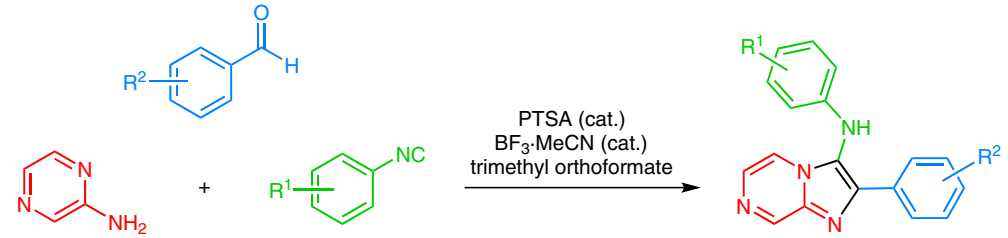

$75-90 \%$

one-pot two-step process
Received: 18.11.2016

Accepted after revision: 06.12.2016

Published online: 31.01 .2017

DOI: 10.1055/s-0036-1588130; Art ID: ss-2016-z0693-op

Abstract 3-Aminoimidazo[1,2-a]pyrazine is an important scaffold that is found in many drugs. This scaffold is rapidly accessible through a Groebke-Blackburn-Bienaymé cyclisation starting from an aminopyrazine, an aldehyde and an isocyanide. A scale-up process of this multicomponent reaction has been achieved in high yield and with excellent purity. The scope and limitations of this process leading to various 3aminoimidazo[1,2-a]pyrazines are disclosed.

Key words cyclisation, Groebke-Blackburn-Bienaymé reaction, onepot process, multicomponent reaction, sulfate salt

3-Aminoimidazo[1,2-a]pyrazines are important building blocks for the pharmaceutical and agrochemical industries. These compounds are accessible through the threecomponent Groebke-Blackburn-Bienaymé cyclisation (GBB reaction) involving an aldehyde, an amine (or preformed imine) and an isonitrile. This multicomponent reaction (MCR) was discovered independently by three pharmaceutical groups at Hoffmann La Roche (Groebke), ${ }^{2}$ Millenium Pharmaceutical (Blackburn) ${ }^{3}$ and Rhone Poulenc (Bienaymé) ${ }^{4}$ in 1998. Recently, it became attractive to the scientific community, especially to pharmaceutical research groups, because a broad variety of target compounds can be made by varying the three compounds, leading to combinatorial libraries. $^{5}$

For our development activities, we required an efficient and scalable synthesis of aminoimidazopyrazine derivatives 1a (Scheme 1) and 1b (Table 2), which are key intermediates for drug candidates designed to treat malaria. ${ }^{6}$ In this manuscript, we report on our progress toward the development of a practical process for the synthesis of intermediate $\mathbf{1 b}$ by using the GBB reaction from easily accessible starting materials: 2-aminopyrazine, 4-fluorobenzaldehyde and 1,2-difluoro-4-isocyanobenzene. We have examined the impact of dehydrating agents, Lewis acids and isocyanide quantity on this three-component reaction. We also studied the scope and limitations of this GBB reaction for various aldehydes and isocyanides and have established optimised reaction conditions.

Our objective was to develop a one-pot process that was suitable for manufacturing 3-aminoimidazo[1,2-a]pyrazine 1 on an industrial scale. Preliminary investigations of the MCR was performed utilising the reaction conditions shown in Scheme 1, in which 2-aminopyrazine (2), benzaldehyde (3a) and isocyanide $\mathbf{4 a}$ reacted in the presence of boron trifluoride and a catalytic amount of $p$-toluene sulfonic acid (PTSA). Under these conditions, the reaction rate appeared to be very slow, as indicated by gas chromatography analyses. After three days, only $49 \%$ conversion was observed.

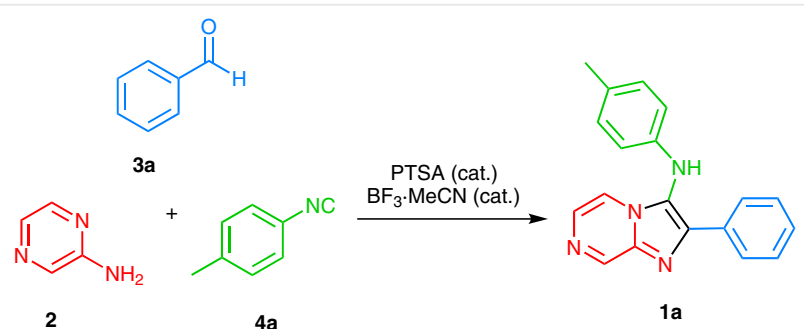

Scheme 1 Toward a one-pot process. Reagents and conditions: 2 (1 equiv), $3 a$ ( 1 equiv), $4 a$ ( 1 equiv), PTSA (1.2 $\mathrm{mol} \%), \mathrm{BF}_{3} \cdot \mathrm{MeCN}(4 \mathrm{~mol} \%)$, r.t., $\mathrm{CH}_{2} \mathrm{Cl}_{2}$.

Although the GBB reaction can be effective in water at elevated temperature, ${ }^{7}$ we thought that the water by-product formed during the reaction could slow down the conversion into product $\mathbf{1}$. To test this hypothesis, we added a dehydrating agent to the previous reaction, which greatly increased its rate (Table 1). GC analyses of the crude reac- 
tion mixture after 17 hours showed that the conversion was increased from $40 \%$ to 64 and $86 \%$ by adding $\mathrm{MgSO}_{4}$ and trimethyl orthoformate, respectively (entries 2 and 3 ). The use of trimethyl orthoformate as dehydrating agent led to a homogeneous reaction mixture, which is more appropriate for industrial processes. Furthermore, unreacted trimethyl orthoformate can be easily separated from the product by evaporation. Product 1a was isolated as a sulfate salt by filtration in $44 \%$ yield. Formation of the sulfate salt was found to be a scalable purification method, which avoided timeconsuming and cost-demanding processes such as column chromatographic purification. The sulfate salt was prepared by adding sulfuric acid to crude $\mathbf{1 a}$ in isopropanol and isolated by simple filtration in good purity.

Table 1 Effect of Dehydrating Agent

\begin{tabular}{lll}
\hline Entry & Dehydrating agent & Yield (\%) \\
\hline 1 & none & 40 \\
2 & $\mathrm{MgSO}_{4}$ (2 equiv) & 64 \\
3 & trimethyl orthoformate (2 equiv) & 80 \\
\hline${ }^{a}$ Yield based on GC analyses of the crude reaction mixture after $17 \mathrm{~h}$.
\end{tabular}

The impact of isocyanide stoichiometry on the GBB reaction was then investigated (Table 2). The preformed imine $\mathbf{5 b}$ was treated with 0.8 to 5 equivalents of isocyanide. The highest yield was obtained when 3 equivalents of isocyanide were used (entry 3 ). Surprisingly, increasing the amount of isocyanide from 3 to 5 equivalents decreased the isolated yield (entry 4). GC analyses of the isolated $\mathbf{1 b}$ sulfate salt revealed that the more isocyanide added, the lower the purity obtained (entries 2 and 3). Supported by ${ }^{1} \mathrm{H}$ NMR analysis of the isolated salt, the major impurity appeared to be a side-product derived from the isocyanide. It could be formed during the reaction or from the prepared isocyanide solution. This point will be discussed later.

Furthermore, the impact of Lewis acids was examined. Imine $\mathbf{5 b}$ was treated with isocyanide $\mathbf{4 b}$ in the presence of a variety of Lewis acids as shown in Table 3. Titanium tetrachloride and aluminium chloride furnished the desired product $\mathbf{1 b}$ in high yields of 83 and $89 \%$, respectively (entries 3 and 4). In terms of purity, the reaction with boron trifluoride-acetonitrile complex appeared to be more attractive. The reaction provided $\mathbf{1 b}$ with excellent purity (>99\%) and in moderate yield (63\%).

We previously pointed out that the quality of isocyanides determines the level of impurities observed in the final product. Isocyanides possess some specific features and can be characterised by their repulsive odour and volatility. They are usually sensitive to acid and hydrolyzed to their corresponding formamide when exposed to aqueous acidic conditions. They also have the property to form a complex

Table 2 Stoichiometry of Isocyanide

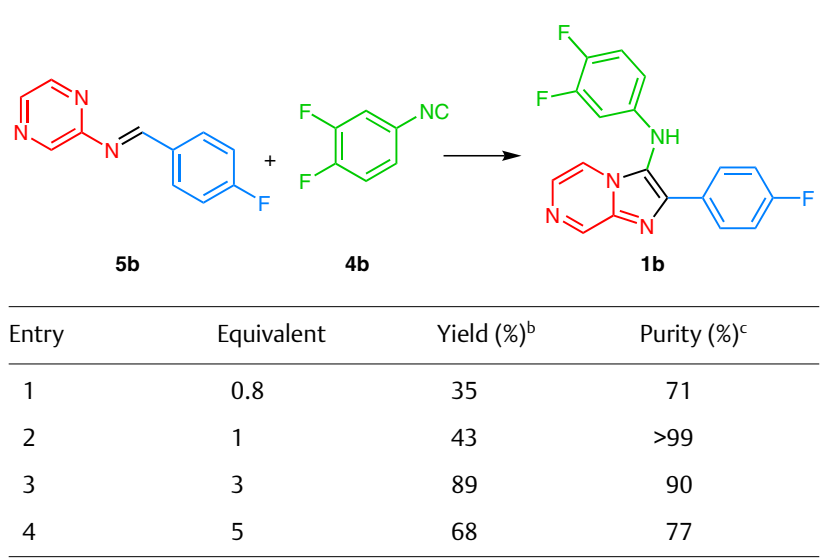

a Reaction conditions: $\mathrm{BF}_{3} \cdot \mathrm{MeCN}$ ( 5 mol\%), trimethyl orthoformate (2 equiv), $\mathrm{CH}_{2} \mathrm{Cl}_{2}$, r.t., 3 days.

${ }^{b}$ Isolated yield of the corresponding sulfate salt.

c Purity based on GC analyses.

catalysed by a Lewis acid. ${ }^{8}$ Such characteristics need to be taken into account for the preparation of isocyanides. Several methods for the preparation of isocyanides are known and have been well described.

Commonly, such compounds are prepared by using the carbylamines method (Hofmann isonitrile synthesis) $)^{9,10}$ or by formamide dehydration ${ }^{11,12}$ (Scheme 2). The isocyanides used in the previous reactions were prepared by reaction of the corresponding aniline with dihalocarbene (Scheme 2, A). In this reaction the dihalocarbene was generated in situ

Table 3 Influence of the Lewis Acid in the GBB Reaction Leading to $\mathbf{1 b}^{\mathbf{a}}$

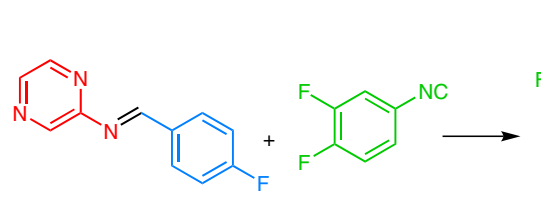

$5 b$

\begin{tabular}{lllc}
\hline Entry & Lewis acid & Yield (\%) & Purity (\%) \\
\hline 1 & $\mathrm{BF}_{3} \cdot \mathrm{MeCN}$ & 63 & $>99$ \\
2 & $\mathrm{ZnCl}_{2}{ }^{\mathrm{d}}$ & 64 & 84 \\
3 & $\mathrm{TiCl}_{4}$ & 83 & 81 \\
4 & $\mathrm{AlCl}_{3}$ & 89 & 79 \\
5 & $\mathrm{Ti}^{\mathrm{i}}(\mathrm{PrO})_{4}$ & 10 & 37 \\
6 & $\mathrm{I}_{2}$ & 84 & 74 \\
7 & $\mathrm{TMSCl}$ & 77 & 74 \\
\hline
\end{tabular}

a Reaction conditions: $\mathbf{5 b}$ ( 1 equiv), $\mathbf{4 b}$ (3 equiv), $\mathrm{BF}_{3} \cdot \mathrm{MeCN}(5 \mathrm{~mol} \%)$, trimethyl orthoformate (2 equiv), $\mathrm{CH}_{2} \mathrm{Cl}_{2}$, r.t., 3 days.

${ }^{b}$ Isolated yield of the corresponding sulfate salt.

c Purity determined by GC analyses.

${ }^{\mathrm{d}} 0.25$ equiv Lewis acid.

e 1 equiv Lewis acid. 


\section{A) Carbylamine method}<smiles>[C-]#[N+]c1ccc(F)c(F)c1</smiles>

B) Dehydration of formamide<smiles>[C-]#[N+]c1ccc(F)c(F)c1</smiles>

Scheme 2 Preparation of isocyanide

from potassium hydroxide and chloroform. Nucleophilic attack by the aniline and subsequent elimination of 2 equivalents of $\mathrm{HCl}$ gave the isocyanide. This method had several disadvantages. First, the reaction did not proceed to full conversion and the remaining aniline could disturb the GBB reaction. An acidic work-up to eliminate this aniline was not feasible because of the instability of isocyanides under such conditions. Furthermore, allowing the reaction to heat, even at lower temperature, could be problematic. Indeed, it has been observed that 1,2-difluorophenyl isocyanide decomposed at $40{ }^{\circ} \mathrm{C}$. Another common way to prepare isocyanide is to dehydrate a formamide (Scheme 2, B). The formamide was prepared under mild conditions by treating the aniline with methyl formate in the presence of NaHMDS at $0{ }^{\circ} \mathrm{C} .{ }^{13}$ Among several dehydrating conditions used to obtain isocyanides from formamides, phosphoryl chloride appeared to be the most efficient. ${ }^{11,12}$ The reaction was performed at $0{ }^{\circ} \mathrm{C}$ and rapidly completed after 1 hour. Moreover, the diisopropylamine hydrochloric salt formed during the reaction precipitated out from the toluene solution and could easily be eliminated by filtration. The remaining traces of diisopropylamine were removed with a very mild acidic workup.

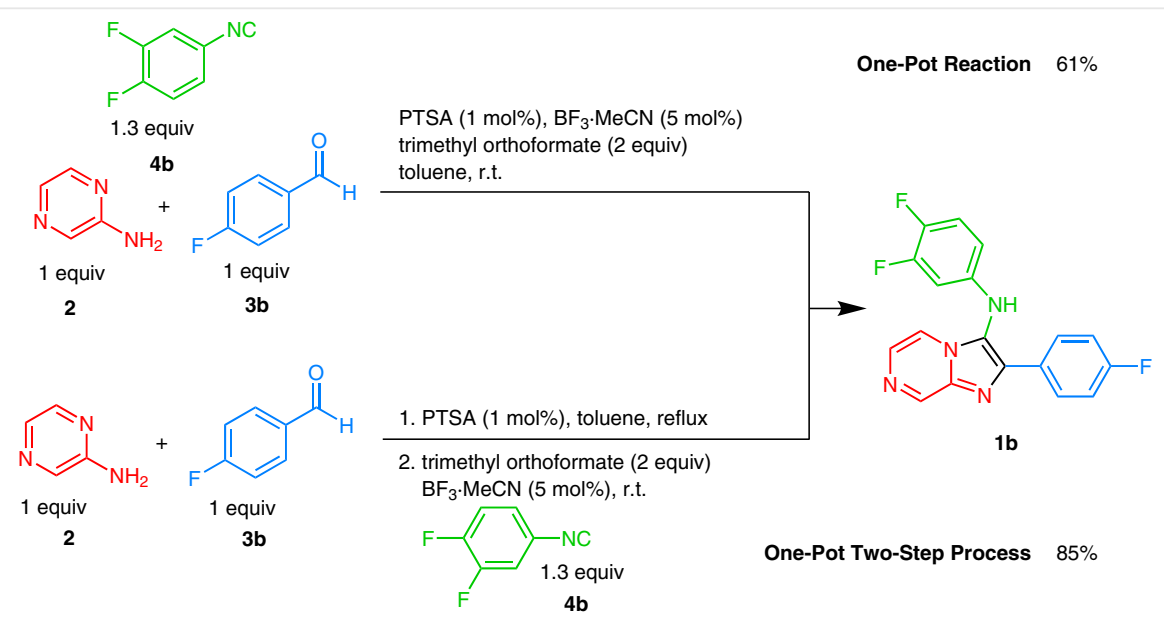

Scheme 3 A scalable one-pot process. Isolated yield of the corresponding salt.
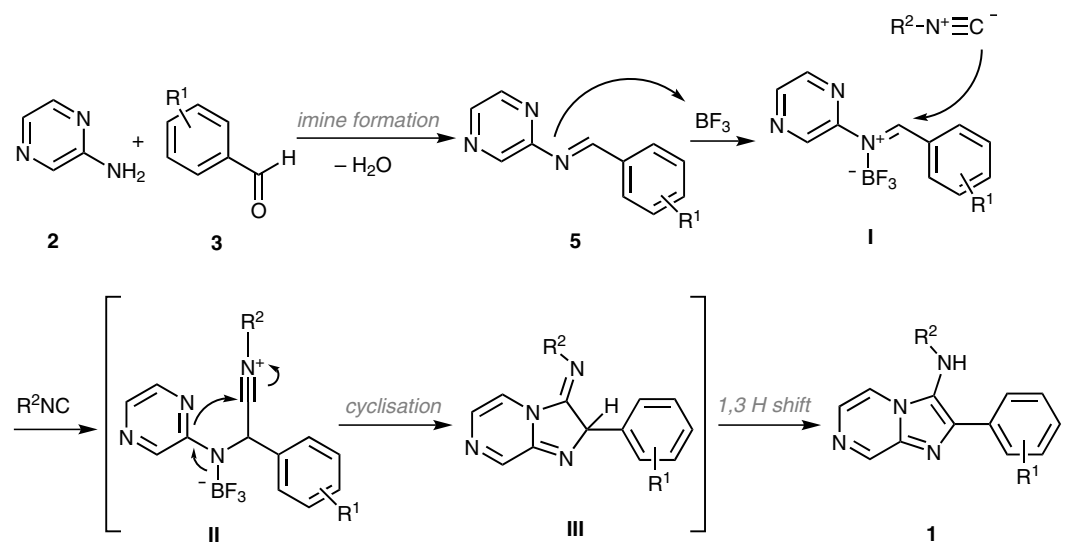
Employing the optimization conditions for the GBB reaction, two one-pot reactions were carried out (Scheme 3). First, aminopyrazine, benzaldehyde and prepared isocyanide solution from formamide were combined in toluene in the presence of PTSA ( $1 \mathrm{~mol} \%$ ), boron trifluoride acetonitrile complex (5 mol\%) and trimethyl orthoformate (2 equiv). After one day at r.t., the sulfate salt of $\mathbf{1} \mathbf{b}$ was isolated in a satisfactory yield of $61 \%$ with excellent purity (>99\% determined by GC analysis). The yield was improved when the imine intermediate was pre-formed (Scheme 3, bottom). In this one-pot, two-step process, aminopyrazine, benzaldehyde and $p$-toluene sulfonic acid ( $1 \mathrm{~mol} \%$ ) were allowed to heat to reflux with a Dean-Stark apparatus for 16 hours. The isocyanide solution, trimethyl orthoformate and boron trifluoride acetonitrile complex ( $5 \mathrm{~mol} \%$ ) were then added at room temperature. After stirring for an additional 16 hours, 1b was isolated as a sulfate salt in $85 \%$ yield. Scale-up of the reaction (100 mmol) provided 36 grams of $\mathbf{1 b}$ in $82 \%$ yield. The last result demonstrated the reproducibility and viability of the process on large scale.

The reaction of imine $\mathbf{5 b}$ with isonitrile $\mathbf{4 b}$ to form product $\mathbf{1 b}$ was followed by FTIR measurements. After the addition of isonitrile, the formation of the desired product 1b increases inversely to the consumption of imine $\mathbf{5 b}$, whereas the isonitrile is consumed faster. Interestingly, the rate of formation of the product or consumption of starting materials is very slow during the 25 min after isonitrile addition to the reaction mixture, then it becomes faster. Finally, the rate of formation/consumption of $\mathbf{1} \mathbf{b}$ and $\mathbf{5 b}$ decreases to approach a plateau after 3.5 hours, while isonitrile is almost completely consumed after 2.5 hours. After about 5 hours, the reaction comes to an end. The rapid consumption of trimethyl orthoformate as soon as isonitrile is added is also notable. The results of this FTIR investigation are summarised in the Supporting Information.

A plausible mechanism for this three-component reaction is depicted in (Scheme 4). Condensation of aminopyrazine with benzaldehyde affords the imine intermediate after releasing water. The resulting imine is complexed with the Lewis acid boron trifluoride to form iminium species $\mathbf{I}$. Isocyanide addition to iminium I furnishes nitrilium intermediate II. Intramolecular addition of the pyrazine nitrogen to the nitrilium carbon gave intermediate III through 5-exodig cyclisation. Aromatisation of III through a $1,3-\mathrm{H}$ shift leads to imidazo[1,2-a]heteroaromatic $\mathbf{1}$.

Table 4 Investigation of the Isocyaniyde

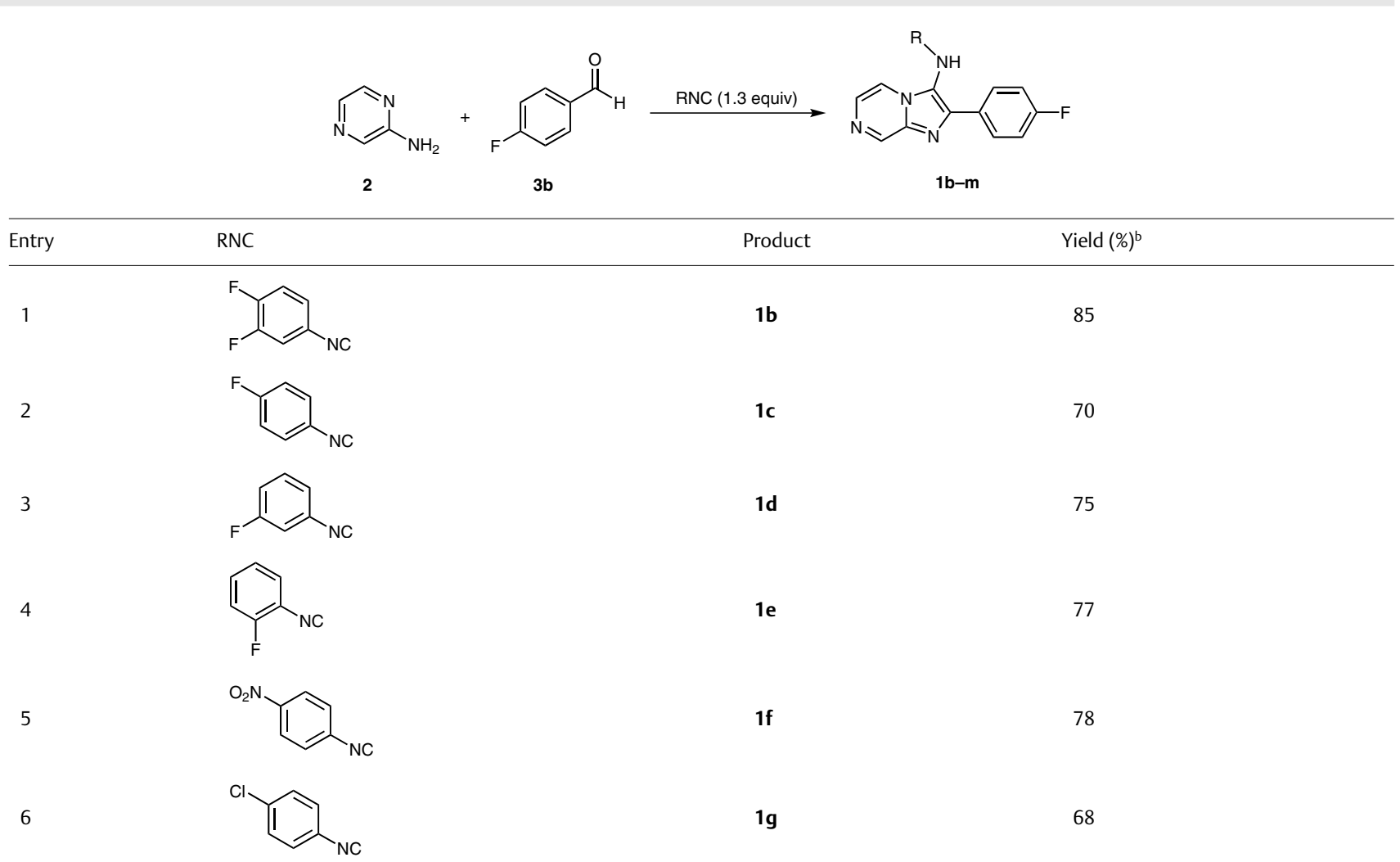




Table 4 (continued)
Entry

Employing the optimised conditions, the scope and limitations of this GBB process were studied. A variety of isocyanides, aromatic, aliphatic, or functionalised, were investigated (Table 4). Electron-poor aryl isocyanides (entries 1-6) furnished products 1 in high yield (68-85\%). Electron-rich p-methoxyphenyl isocyanide (entry 8 ) afforded product $\mathbf{1 i}$ in an excellent yield of $90 \%$. Both aliphatic and functionalised isocyanides also proceeded in good yields (66-87\%; entries 9-12). These results demonstrated the good tolerance of the GBB reaction toward isocyanides.

Various aldehydes were also explored (Table 5). Reactions for both electron-poor and electron-rich benzaldehydes and 3,4-difluorophenyl isocyanide $\mathbf{4 b}$ provided $\mathbf{1 s}$ in high yields (82-95\%; entries $1-5$ ). When both isocyanide and aldehyde are electron-rich, the yield was lower. For instance, the reaction for $p$-methoxyphenyl isocyanide and $p$ methoxybenzaldehyde afforded product $1 \mathrm{~s}$ in $37 \%$ yield determined by ${ }^{1} \mathrm{H}$ NMR spectroscopic analysis of the crude, result not shown. In comparison, the reaction for $p$-methoxyphenyl isocyanide and electron-poor 4-fluorobenzaldehyde gave $\mathbf{1 i}$ in an excellent yield of $90 \%$ (Table 4, entry 8 ). Reaction of a heteroaromatic aldehyde, such as pyridine aldehyde, resulted in only $9 \%$ conversion (entry 6). Reaction of cyclohexanecarboxaldehyde and 3,4-difluorophenyl isocyanide furnished 1s in 36\% (entry 7). No conversion was observed when both isocyanide and aldehyde were aliphatic (entry 8).
To further broaden the scope of this GBB process, we replaced 2-aminopyrazine with 2-aminopyridine 6 (Scheme 5 ). Reaction of $\mathbf{6}$ with fluorobenzaldehyde $\mathbf{3 b}$ and difluorophenylisocyanide $\mathbf{4 b}$ gave imidazo[1,2-a]pyridine $\mathbf{7}$ in a good yield of $67 \%$. Encouraged by this promising result, we are currently investigating other scaffolds that we want to disclose in a future manuscript.

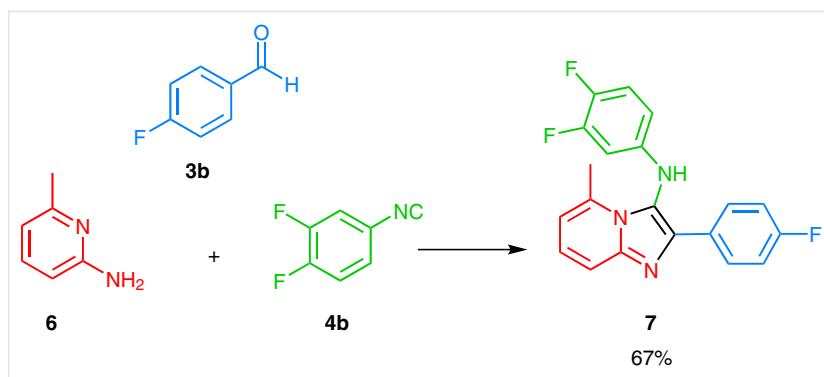

Scheme 5 Preliminary result for the formation of 3-aminoimidazo[1,2a]pyridine. Reagents and conditions: 1.6 ( 1 equiv), $\mathbf{3 b}$ (1 equiv), PTSA (1 mol\%), toluene, reflux, 16 h; $2.4 \mathbf{b}$ ( 1.3 equiv), $\mathrm{BF}_{3}-\mathrm{MeCN}$ ( 5 mol\%), trimethyl orthoformate (2 equiv), $\mathrm{CH}_{2} \mathrm{Cl}_{2}$, r.t., $24 \mathrm{~h}$.

In conclusion, a scalable process employing a one-pot, three-component, Groebke-Blackburn-Bienaymé type reaction was developed for the syntheses of 3-aminoimidazo[1,2-a]pyrazines in high yield with excellent purity. It was demonstrated that both Lewis acid boron trifluoride and dehydrating agent trimethyl orthoformate were essential to promote this reaction leading to higher yields. The 
Table 5 Investigation of the Aldehydes ${ }^{\mathrm{a}}$

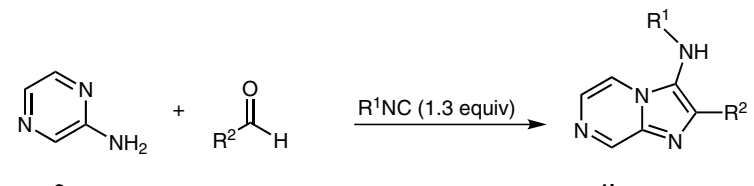

2

$1 b, n-u$

Entry

a Reaction conditions: 1.2 (1 equiv), $\mathrm{R}^{2}$-CHO (1 equiv), PTSA ( 1 mol\%), toluene, reflux, $16 \mathrm{~h} ; 2$. $\mathrm{R}^{1}-\mathrm{NC}\left(1.3\right.$ equiv), $\mathrm{BF}_{3} \cdot \mathrm{MeCN}(5 \mathrm{~mol} \%)$, trimethyl orthoformate (2 equiv), $\mathrm{CH}_{2} \mathrm{Cl}_{2}$, r.t., 24 h.

${ }^{b}$ Isolated yield of the sulfate salt.

' Conversion determined by GC analysis of the reaction mixture.

No reaction.

optimised process required no halogenated solvents or heterogeneous conditions. Most products could be isolated and purified by forming their corresponding sulfate salts. Furthermore, this GBB type of reaction has been shown to be versatile with respect to a range of isocyanides and aldehydes, and can be used to synthesise a large pool of valuable 3-aminoimidazo[1,2-a]pyrazines.
The solvents used were bulk quality, used in our scale-up facilities. The starting materials used were purchased from commercial sources (Sigma Aldrich; ABCR). The reactions described in this manuscript were performed in standard laboratory glassware. The NMR spectra were recorded on a Bruker Avance $400\left({ }^{1} \mathrm{H}\right.$ NMR: $400 \mathrm{MHz} ;{ }^{13} \mathrm{C}$ NMR: $100 \mathrm{MHz} ;{ }^{19} \mathrm{~F}$ NMR: $\left.376 \mathrm{MHz}\right)$ or Bruker BBO $\left({ }^{1} \mathrm{H}\right.$ NMR: $\left.500 \mathrm{MHz}\right)$ spectrometer, measured in the solvent indicated, with tetramethylsilane (TMS) as an internal standard. Coupling constants $(J)$ are reported in hertz $(\mathrm{Hz})$. The LC-HRMS analyses were performed by using electrospray ionisation in positive ion modus after separation by liquid chromatography (Nexera from Shimadzu). The elemental composition was derived from the averaged mass spectra acquired at the high resolution of about 30,000 with an LTQ Orbitrap XL mass spectrometer (Thermo Scientific). The high-mass accuracy below $1 \mathrm{ppm}$ was obtained by using a lock mass. GC spectra were measured on a HP-5890 GC with an FID detector, HPLC on an Agilent 1100 with a UV detector.

\section{Groebke-Blackburn-Bienaymé Type Cyclisation; General Proce- dure}

A reactor equipped with a Dean-Stark reflux condenser was charged with 2-aminopyrazine (1 equiv), aldehyde (1 equiv), PTSA (1.2 mol\%), and toluene $(0.5 \mathrm{M})$ under an atmosphere of nitrogen. The reaction mixture was heated to $110^{\circ} \mathrm{C}$ for $16 \mathrm{~h}$. After cooling the mixture to r.t., trimethyl orthoformate (2 equiv) and $\mathrm{BF}_{3} \cdot \mathrm{MeCN} 1 \mathrm{M}(4 \mathrm{~mol} \%)$ were added. A freshly prepared solution of isocyanide (1.3 equiv) was then added dropwise and the reaction mixture was stirred at r.t. for $24 \mathrm{~h}$. $\mathrm{MeOH}$ (about 6 equiv) was added and the mixture was stirred for another $10 \mathrm{~min}$. The reaction mixture was concentrated under reduced pressure at $50{ }^{\circ} \mathrm{C}$. The crude product was dissolved in a minimum amount of $i$-PrOH at reflux. Concentrated sulfuric acid (1.3 equiv) was added slowly to the solution. The precipitation mixture was slowly cooled to $-10^{\circ} \mathrm{C}$. The precipitate was filtered, rinsed with cold $i$-PrOH (minimum amount) and dried under reduced pressure to furnish the desired product as a sulfate salt.

\section{2-Phenyl- $N$-( $p$-tolyl)imidazo[1,2-a]pyrazin-3-amine (1a)}

The corresponding sulfate salt was obtained as a dark-orange solid. ${ }^{1} \mathrm{H}$ NMR (400 MHz, DMSO + $\left.\mathrm{D}_{2} \mathrm{O}\right): \delta=9.46(\mathrm{~s}, 1 \mathrm{H}), 8.24(\mathrm{~d}, J=4.5 \mathrm{~Hz}$, $1 \mathrm{H}), 8.05(\mathrm{~d}, J=4.5 \mathrm{~Hz}, 1 \mathrm{H}), 8.02(\mathrm{~d}, J=7.5 \mathrm{~Hz}, 2 \mathrm{H}), 7.40-7.47(\mathrm{~m}$, $3 \mathrm{H}), 6.96(\mathrm{~d}, J=7.8 \mathrm{~Hz}, 2 \mathrm{H}), 6.52(\mathrm{~d}, J=7.5 \mathrm{~Hz}, 2 \mathrm{H}), 2.15(\mathrm{~s}, 3 \mathrm{H})$.

${ }^{13} \mathrm{C}$ NMR $\left(100 \mathrm{MHz}\right.$, DMSO $\left.+\mathrm{D}_{2} \mathrm{O}\right): \delta=142.2,141.1,138.4,135.5$, $131.1,130.5,130.1,129.4,129.2,127.6,124.7,124.7,118.8,114.5$, 20.5 .

HR-LC MS: $m / z[M+H]^{+}$calcd for $\mathrm{C}_{19} \mathrm{H}_{17} \mathrm{~N}_{4}{ }^{+}$: 301.14477; found: 301.14482 .

\section{$N$-(2,3-Difluorophenyl)-2-(4-fluorophenyl)imidazo[1,2-a]pyrazin-} 3-amine (1b)

The corresponding sulfate salt was obtained as a mustard-yellow solid.

Yield: $1.33 \mathrm{~g}(85 \%)$.

${ }^{1} \mathrm{H}$ NMR (400 MHz, DMSO + $\left.\mathrm{D}_{2} \mathrm{O}\right): \delta=9.35(\mathrm{~s}, 1 \mathrm{H}), 8.28(\mathrm{dd}, J=5.0$, $1.3 \mathrm{~Hz}, 1 \mathrm{H}), 8.00-8.05(\mathrm{~m}, 3 \mathrm{H}), 7.30(\mathrm{t}, J=9.0 \mathrm{~Hz}, 2 \mathrm{H}), 7.19(\mathrm{q}$, $J=9.5 \mathrm{~Hz}, 1 \mathrm{H}), 6.62(\mathrm{ddd}, J=12.5,6.8,2.8 \mathrm{~Hz}, 1 \mathrm{H}), 6.37-6.40(\mathrm{~m}$, $1 \mathrm{H})$.

${ }^{13} \mathrm{C}$ NMR (100 MHz, DMSO): $\delta=163.1$ (d, $J=247.3 \mathrm{~Hz}$ ), 150.6 (dd, $J=244.3,12.4 \mathrm{~Hz}), 143.8$ (dd, $J=236.2,12.4 \mathrm{~Hz}), 141.7$ (d, $J=7.3 \mathrm{~Hz}$ ), 141.2, 139.8, 136.4, 129.8 (2C), 128.3, 125.5, 123.0, 118.9, 118.7 (d, $J=18.3 \mathrm{~Hz}), 116.4$ (d, $J=21.2 \mathrm{~Hz}, 2 \mathrm{C}), 110.3,103.4(\mathrm{~d}, J=21.3 \mathrm{~Hz})$. 
HR-LC MS: $m / z[\mathrm{M}+\mathrm{H}]^{+}$calcd for $\mathrm{C}_{18} \mathrm{H}_{12} \mathrm{~F}_{3} \mathrm{~N}_{4}^{+}$: 341.10086; found: 341.10108.

\section{$N$-(3-Fluorophenyl)-2-(4-fluorophenyl)imidazo[1,2-a]pyrazin-3- amine (1c)}

The corresponding sulfate salt was obtained as a mustard-yellow solid.

Yield: $1.36 \mathrm{~g}$ (70\%).

${ }^{1} \mathrm{H} \mathrm{NMR}$ (400 MHz, DMSO): $\delta=10.93(\mathrm{br}, 2 \mathrm{H}), 9.49$ (d, $J=1.0 \mathrm{~Hz}, 1 \mathrm{H}$ ), $8.79(\mathrm{~s}, 1 \mathrm{H}), 8.32(\mathrm{dd}, J=5.1,1.2 \mathrm{~Hz}, 1 \mathrm{H}), 8.06-8.09(\mathrm{~m}, 1 \mathrm{H}), 8.08$ (dd, $J=9.3,4.5 \mathrm{~Hz}, 2 \mathrm{H}$ ), 7.32 (t, $J=9.0 \mathrm{~Hz}, 2 \mathrm{H}$ ), 7.01 (t, $J=8.8 \mathrm{~Hz}$, $2 \mathrm{H}), 6.64(\mathrm{dd}, J=8.9,4.3 \mathrm{~Hz}, 1 \mathrm{H})$.

${ }^{13} \mathrm{C}$ NMR (100 MHz, DMSO): $\delta=163.0$ (d, $J=247.2 \mathrm{~Hz}$ ), 156.8 (d, $J=235.5 \mathrm{~Hz}), 141.3,140.4,139.5,136.1,129.8(\mathrm{~d}, J=8.8 \mathrm{~Hz}, 2 \mathrm{C})$, 128.4, 125.2, 124.0, 118.8, 116.5 (d, J=22.0 Hz, 2C), 116.4 (d, $J=21.3 \mathrm{~Hz}, 2 \mathrm{C}), 115.7$ (d, $J=7.3 \mathrm{~Hz}, 2 \mathrm{C}$ ).

HR-LC MS: $m / z[\mathrm{M}+\mathrm{H}]^{+}$calcd for $\mathrm{C}_{18} \mathrm{H}_{13} \mathrm{~F}_{2} \mathrm{~N}_{4}^{+}$: 323.11028; found: 323.11047.

\section{$N$-(3-Fluorophenyl)-2-(4-fluorophenyl)imidazo[1,2-a]pyrazin-3- amine (1d)}

The corresponding sulfate salt was obtained as a mustard-yellow solid.

Yield: $1.18 \mathrm{~g}$ (75\%).

${ }^{1} \mathrm{H}$ NMR (400 MHz, DMSO): $\delta=10.36$ (br, $\left.2 \mathrm{H}\right), 9.48(\mathrm{~d}, J=0.8 \mathrm{~Hz}, 1 \mathrm{H}$ ), 8.99 (s, $1 \mathrm{H}), 8.33$ (dd, $J=4.8,0.8 \mathrm{~Hz}, 1 \mathrm{H}), 8.06-8.10(\mathrm{~m}, 3 \mathrm{H}), 7.33$ (t, $J=8.9 \mathrm{~Hz}, 2 \mathrm{H}), 7.18(\mathrm{dd}, J=15.1,8.0 \mathrm{~Hz}, 1 \mathrm{H}), 6.59(\mathrm{td}, J=8.5,2.1 \mathrm{~Hz}$, $1 \mathrm{H}), 6.41-6.47$ (m, $2 \mathrm{H})$.

${ }^{13} \mathrm{C}$ NMR (100 MHz, DMSO): $\delta=163.8$ (d, $J=242.0 \mathrm{~Hz}$ ), 163.1 (d, $J=247.4 \mathrm{~Hz}$ ), 146.3 (d, $J=10.8 \mathrm{~Hz}), 141.4,139.8,136.4,131.7$ (d, $J=10.0 \mathrm{~Hz}), 129.8$ (d, $J=8.5 \mathrm{~Hz}, 2 \mathrm{C}), 128.2(\mathrm{~d}, J=3.1 \mathrm{~Hz}), 125.5,122.9$, $118.9,116.5$ (d, $J=21.6 \mathrm{~Hz}, 2 \mathrm{C}), 110.5,106.5$ (d, $J=21.6 \mathrm{~Hz}), 101.3$ (d, $J=26.2 \mathrm{~Hz}$ ).

HR-LC MS: $m / z[\mathrm{M}+\mathrm{H}]^{+}$calcd for $\mathrm{C}_{18} \mathrm{H}_{13} \mathrm{~F}_{2} \mathrm{~N}_{4}{ }^{+}$: 323.11028; found: 323.11042 .

\section{$N$-(2-Fluorophenyl)-2-(4-fluorophenyl)imidazo[1,2-a]pyrazin-3- amine (1e)}

The corresponding sulfate salt was obtained as a mustard-yellow solid.

Yield: $1.11 \mathrm{~g}(77 \%)$.

${ }^{1} \mathrm{H}$ NMR (400 MHz, DMSO): $\delta=10.84(\mathrm{br}, 2 \mathrm{H}), 9.46(\mathrm{~d}, J=1.3 \mathrm{~Hz}, 1 \mathrm{H}$ ), $8.66(\mathrm{~s}, 1 \mathrm{H}), 8.41(\mathrm{dd}, J=5.0,1.3 \mathrm{~Hz}, 1 \mathrm{H}), 8.05-8.08(\mathrm{~m}, 3 \mathrm{H}), 7.32(\mathrm{t}$, $J=8.9 \mathrm{~Hz}, 2 \mathrm{H}), 7.25$ (ddd, $J=11.9,8.0,1.5 \mathrm{~Hz}, 1 \mathrm{H}), 6.78-6.88(\mathrm{~m}$, $2 \mathrm{H}), 6.28$ (td, $J=8.3,1.5 \mathrm{~Hz}, 1 \mathrm{H})$.

${ }^{13} \mathrm{C}$ NMR (100 MHz, DMSO): $\delta=163.1$ (d, $J=247.2 \mathrm{~Hz}$ ), 152.0 (d, $J=241.4 \mathrm{~Hz}), 141.9,139.7,136.3,132.0(\mathrm{~d}, J=11.8 \mathrm{~Hz}), 129.7$ (d, $J=8.8 \mathrm{~Hz}, 2 \mathrm{C}), 128.4,125.5,125.1,122.9,120.7,119.0,116.4(\mathrm{~d}$, $J=21.3 \mathrm{~Hz}, 2 \mathrm{C}), 116.3-116.5(\mathrm{~m}), 115.2$.

HR-LC MS: $m / z[M+H]^{+}$cald for $\mathrm{C}_{18} \mathrm{H}_{13} \mathrm{~F}_{2} \mathrm{~N}_{4}{ }^{+}$: 323.11028; found: 323.11051 .

\section{$\mathrm{N}$-(4-Nitrophenyl)-2-(4-fluorophenyl)imidazo[1,2-a]pyrazin-3- amine (1f)}

The corresponding sulfate salt was obtained as a mustard-yellow solid.
Yield: $1.40 \mathrm{~g}$ (78\%).

${ }^{1} \mathrm{H} \mathrm{NMR}\left(400 \mathrm{MHz}\right.$, DMSO $\left.+\mathrm{D}_{2} \mathrm{O}\right): \delta=9.42(\mathrm{~d}, J=1.1 \mathrm{~Hz}, 1 \mathrm{H}), 8.32(\mathrm{dd}$, $J=5.0,1.1 \mathrm{~Hz}, 1 \mathrm{H}), 8.02-8.07(\mathrm{~m}, 5 \mathrm{H}), 7.31(\mathrm{t}, J=8.9 \mathrm{~Hz}, 2 \mathrm{H}), 6.75(\mathrm{~d}$, $J=8.7 \mathrm{~Hz}, 2 \mathrm{H})$.

${ }^{13} \mathrm{C}$ NMR (100 MHz, DMSO): $\delta=163.1$ (d, $\left.J=247.2 \mathrm{~Hz}\right), 151.0(2 \mathrm{C})$, 141.4, 140.7, 140.1, 136.9, 129.7 (d, 2C, J = 8.4 Hz), 128.3, 126.6 (2C), $126.4,120.9,118.8,116.5$ (d, $J=22.4 \mathrm{~Hz}, 2 \mathrm{C}), 114.0$.

HR-LC MS: $m / z[\mathrm{M}+\mathrm{H}]^{+}$calcd for $\mathrm{C}_{18} \mathrm{H}_{13} \mathrm{FN}_{4} \mathrm{O}_{2}{ }^{+}$: 350.10478; found: 350.10483.

\section{$N$-(4-Chlorophenyl)-2-(4-fluorophenyl)imidazo[1,2-a]pyrazin-3-} amine (1g)

The corresponding sulfate salt was obtained as a mustard-yellow solid.

Yield: $1.29 \mathrm{~g}(68 \%)$.

${ }^{1} \mathrm{H}$ NMR (400 MHz, DMSO): $\delta=10.45$ (br, $2 \mathrm{H}$ ), 9.46 (s, $1 \mathrm{H}$ ), 8.89 (s, $\left.1 \mathrm{H}, \mathrm{HSO}_{4^{-}}\right), 8.30(\mathrm{~d}, J=5.0 \mathrm{~Hz}, 1 \mathrm{H}), 8.05-8.08(\mathrm{~m}, 3 \mathrm{H}), 7.33(\mathrm{t}$, $J=8.9 \mathrm{~Hz}, 2 \mathrm{H}), 7.19$ (d, $J=8.9 \mathrm{~Hz}, 2 \mathrm{H}), 6.62(\mathrm{~d}, J=8.9 \mathrm{~Hz}, 2 \mathrm{H})$.

${ }^{13} \mathrm{C}$ NMR (100 MHz, DMSO): $\delta=163.1$ (d, $J=247.2 \mathrm{~Hz}$ ), 143.1, 141.5, 139.6, 136.2, 129.8 (4C), 128.3, 125.2, 123.7, 123.3, 119.0, 116.5 (d, $J=21.2 \mathrm{~Hz}, 2 \mathrm{C}), 116.0(2 \mathrm{C})$.

HR-LC MS: $m / z[\mathrm{M}+\mathrm{H}]^{+}$cald for $\mathrm{C}_{18} \mathrm{H}_{13} \mathrm{ClFN}_{4}^{+}$: 339.08073; found: 339.08092.

$N$-(p-Methylphenyl)-2-(4-fluorophenyl)imidazo[1,2-a]pyrazin-3amine (1h)

The corresponding sulfate was obtained as a yellow-brown solid. Yield: $1.11 \mathrm{~g}(62 \%)$.

${ }^{1} \mathrm{H}$ NMR (400 MHz, DMSO): $\delta=9.48(\mathrm{~s}, 1 \mathrm{H}), 9.05$ (br, $\left.2 \mathrm{H}\right), 8.65(\mathrm{~s}, 1 \mathrm{H}$, $\left.\mathrm{HSO}_{4^{-}}\right), 8.26(\mathrm{~d}, J=5.0 \mathrm{~Hz}, 1 \mathrm{H}), 8.09(\mathrm{dd}, J=8.5,5.5 \mathrm{~Hz}, 2 \mathrm{H}), 8.07$ (d, $J=5.0 \mathrm{~Hz}, 1 \mathrm{H}), 7.32(\mathrm{t}, J=8.5 \mathrm{~Hz}, 2 \mathrm{H}), 6.98(\mathrm{~d}, J=8.2 \mathrm{~Hz}, 2 \mathrm{H}), 6.53(\mathrm{~d}$, $J=8.2 \mathrm{~Hz}, 2 \mathrm{H}), 2.17\left(\mathrm{~s}, 3 \mathrm{H}, \mathrm{CH}_{3}\right)$.

${ }^{13} \mathrm{C}$ NMR (100 MHz, $\left.100 \mathrm{MHz}, \mathrm{DMSO}\right): \delta=163.1$ (d, $J=247.2 \mathrm{~Hz}$ ), 141.6, 141.3, 139.0, 135.9, 130.5 (2C), 129.8 (d, $J=8.1 \mathrm{~Hz}, 2 \mathrm{C}$ ), 129.0, 128.3, 124.6 (2C), 119.0, 116.4 (d, $J=22.0 \mathrm{~Hz}, 2 \mathrm{C}$ ), 114.6 (2C), 20.6 $\left(\mathrm{CH}_{3}\right)$.

HR-LC MS: $m / z[\mathrm{M}+\mathrm{H}]^{+}$cald for $\mathrm{C}_{19} \mathrm{H}_{16} \mathrm{FN}_{4}^{+}$: 319.13535 ; found: 319.13543.

$\mathrm{N}$-(4-Methoxyphenyl)-2-(4-fluorophenyl)imidazo[1,2-a]pyrazin3-amine (1i)

The corresponding sulfate salt was obtained as an ochre solid.

Yield: $1.41 \mathrm{~g}(90 \%)$.

${ }^{1} \mathrm{H}$ NMR (400 MHz, DMSO): $\delta=9.47$ (s, $1 \mathrm{H}$ ), 9.47 (br, $2 \mathrm{H}$ ), 8.57 (br s, $1 \mathrm{H}), 8.26(\mathrm{~d}, J=6.0 \mathrm{~Hz}, 1 \mathrm{H}), 8.03-8.07(\mathrm{~m}, 3 \mathrm{H}), 7.31(\mathrm{t}, J=8.9 \mathrm{~Hz}$, $2 \mathrm{H}), 6.77(\mathrm{~d}, J=9.0 \mathrm{~Hz}, 2 \mathrm{H}), 6.58(\mathrm{~d}, J=9.0 \mathrm{~Hz}, 2 \mathrm{H}), 3.64\left(\mathrm{~s}, 3 \mathrm{H}, \mathrm{CH}_{3}\right)$. ${ }^{13} \mathrm{C}$ NMR (100 MHz, DMSO): $\delta=163.1$ (d, $J=247.3 \mathrm{~Hz}$ ), 153.8, 141.7, $138.4,136.9,135.6,129.9$ (d, $J=8.1 \mathrm{~Hz}, 2 \mathrm{C}), 128.2,125.6,123.9,119.0$, $116.4(\mathrm{~d}, J=22.0 \mathrm{~Hz}, 2 \mathrm{C}), 116.0(2 \mathrm{C}), 115.4(2 \mathrm{C}), 55.7\left(\mathrm{CH}_{3}\right)$.

HR-LC MS: $m / z[\mathrm{M}+\mathrm{H}]^{+}$cald for $\mathrm{C}_{19} \mathrm{H}_{16} \mathrm{FN}_{4} \mathrm{O}^{+}$: 335.13027; found: 335.13043.

$N$-(Cyclohexyl)-2-(4-fluorophenyl)imidazo[1,2-a]pyrazin-3-amine (1j)

The corresponding sulfate salt was obtained as a yellow solid. Yield: $0.89 \mathrm{~g}(66 \%)$. 
${ }^{1} \mathrm{H}$ NMR $\left(400 \mathrm{MHz}, \mathrm{DMSO}+\mathrm{D}_{2} \mathrm{O}\right): \delta=9.09(\mathrm{~s}, 1 \mathrm{H}), 8.53(\mathrm{~d}, J=5.3 \mathrm{~Hz}$, $1 \mathrm{H}), 8.03$ (dd, $J=8.5,5.5 \mathrm{~Hz}, 2 \mathrm{H}), 7.86(\mathrm{~d}, J=5.3 \mathrm{~Hz}, 1 \mathrm{H}), 7.33(\mathrm{t}$, $J=8.9 \mathrm{~Hz}, 2 \mathrm{H}), 2.91-2.96(\mathrm{~m}, 1 \mathrm{H}), 1.68(\mathrm{~d}, J=10.5 \mathrm{~Hz}, 2 \mathrm{H}), 1.57(\mathrm{~d}$, $J=12.0 \mathrm{~Hz}, 2 \mathrm{H}), 1.41(\mathrm{~m}, 1 \mathrm{H}), 1.21-1.26(\mathrm{~m}, 2 \mathrm{H}), 0.92-1.07(\mathrm{~m}, 3 \mathrm{H})$. ${ }^{13} \mathrm{C}$ NMR (100 MHz, DMSO): $\delta=162.99$ (d, $\left.J=247.2 \mathrm{~Hz}\right), 140.1,135.8$, 133.8, 133.0, 130.2 (d, $J=8.1 \mathrm{~Hz}, 2 \mathrm{C}), 129.2,121.5,118.2,116.3$ (d, $J=22.0 \mathrm{~Hz}, 2 \mathrm{C}), 56.3,34.0,25.5,25.1$.

HR-LC MS: $m / z[M+\mathrm{H}]^{+}$cald for $\mathrm{C}_{18} \mathrm{H}_{20} \mathrm{FN}_{4}^{+}$: 311.16665; found: 311.16677.

\section{$\mathrm{N}$-(Isopropyl)-2-(4-fluorophenyl)imidazo[1,2-a]pyrazin-3-amine (1k)}

The corresponding sulfate salt was obtained as a mustard-yellow solid.

Yield: $0.80 \mathrm{~g}$ (87\%).

${ }^{1} \mathrm{H}$ NMR (400 MHz, DMSO): $\delta=10.0-9.0$ (2 H, br s), 9.34 (s, $1 \mathrm{H}$ ), 8.75 (d, $J=5.3 \mathrm{~Hz}, 1 \mathrm{H}), 8.10(\mathrm{dd}, J=8.7,5.7 \mathrm{~Hz}, 2 \mathrm{H}), 8.02(\mathrm{~d}, J=5.5 \mathrm{~Hz}$, $1 \mathrm{H}$ ), 7.39 (t, $J=8.9 \mathrm{~Hz}, 2 \mathrm{H}$ ), 3.38 (sept, $J=6.3 \mathrm{~Hz}, 1 \mathrm{H}$ ), 1.09 (d, $J=6.3 \mathrm{~Hz}, 6 \mathrm{H})$.

${ }^{13} \mathrm{C}$ NMR (100 MHz, DMSO): $\delta=163.0$ (d, $\left.J=247.2 \mathrm{~Hz}\right), 140.2,135.9$, $133.8,133.3,130.1$ (d, $J=8.1 \mathrm{~Hz}, 2 \mathrm{C}), 129.2,121.5,118.2,116.4$ (d, $J=22.0 \mathrm{~Hz}, 2 \mathrm{C}), 49.0,23.6(2 \mathrm{C})$.

HR-LC MS: $m / z[\mathrm{M}+\mathrm{H}]^{+}$calcd for $\mathrm{C}_{15} \mathrm{H}_{16} \mathrm{FN}_{4}^{+}:$271.13535; found: 271.13531 .

\section{$N$-(p-Toluenesulfonylmethyl)-2-(4-fluorophenyl)imidazo[1,2- a]pyrazin-3-amine (11)}

Purification of the crude was conducted differently. The crude material was suspended in EtOAC and stirred at $50{ }^{\circ} \mathrm{C}$ for a few hours. The suspension was then cooled to $0{ }^{\circ} \mathrm{C}$ and filtered off. The solid was washed with EtOAc and $\mathbf{1 1}$ was obtained as a pale-brown solid.

Yield: $0.40 \mathrm{~g}$ (70\%).

${ }^{1} \mathrm{H}$ NMR (400 MHz, DMSO): $\delta=8.77(\mathrm{~s}, 1 \mathrm{H}), 8.09(\mathrm{~d}, J=3.8 \mathrm{~Hz}, 1 \mathrm{H})$, 7.86-7.89 (m, $2 \mathrm{H}), 7.76(\mathrm{~d}, J=4.8 \mathrm{~Hz}, 1 \mathrm{H}), 7.41(\mathrm{~d}, J=8.0 \mathrm{~Hz}, 2 \mathrm{H})$, $7.18(\mathrm{t}, J=8.8 \mathrm{~Hz}, 2 \mathrm{H}), 7.11(\mathrm{~d}, J=8.0 \mathrm{~Hz}, 2 \mathrm{H}), 6.46(\mathrm{t}, J=6.9 \mathrm{~Hz}, 1 \mathrm{H})$, $4.54(\mathrm{~d}, J=7.0 \mathrm{~Hz}, 2 \mathrm{H}), 2.22\left(\mathrm{~s}, 3 \mathrm{H}, \mathrm{CH}_{3}\right)$.

${ }^{13} \mathrm{C}$ NMR (100 MHz, DMSO): $\delta=162.4$ (d, $\left.J=245.8 \mathrm{~Hz}\right), 144.7,142.7$, 136.2, 136.0, 135.0, 129.9 (3C), 129.6 (d, $J=8.1 \mathrm{~Hz}, 2 \mathrm{C}$ ), 128.8, 128.1 (2C), 125.2, 117.2, 116.0 (d, $J=21.3 \mathrm{~Hz}, 2 \mathrm{C}), 68.7,21.5$.

HR-LC MS: $m / z[\mathrm{M}+\mathrm{H}]^{+}$calcd for $\mathrm{C}_{20} \mathrm{H}_{18} \mathrm{FN}_{4} \mathrm{O}_{2}{ }^{+}$: 397.11290; found: 397.11288.

$N$-(3,4-Difluorophenyl)-2-(4-chlorophenyl)imidazo[1,2-a]pyrazin3-amine (1n)

The corresponding sulfate salt was obtained as a yellow solid.

Yield: $0.93 \mathrm{~g}$ (86\%).

${ }^{1} \mathrm{H}$ NMR $\left(400 \mathrm{MHz}\right.$, DMSO $\left.+\mathrm{D}_{2} \mathrm{O}\right): \delta=9.32(\mathrm{~s}, 1 \mathrm{H}), 8.27(\mathrm{~d}, J=4.6 \mathrm{~Hz}$, $1 \mathrm{H}), 7.96-8.01(\mathrm{~m}, 3 \mathrm{H}), 7.49(\mathrm{~d}, J=8.5 \mathrm{~Hz}, 2 \mathrm{H}), 7.16(\mathrm{dt}, J=9.8$, $9.2 \mathrm{~Hz}, 1 \mathrm{H}), 6.57-6.61(\mathrm{~m}, 1 \mathrm{H}), 6.35-6.38(\mathrm{~m}, 1 \mathrm{H})$.

${ }^{13} \mathrm{C}$ NMR (100 MHz, DMSO): $\delta=150.5(J=244.3,13.9 \mathrm{~Hz}, \mathrm{dd}), 143.9$ $(J=237.0,13.2 \mathrm{~Hz}, \mathrm{dd}), 141.6$ (br), 141.0, 140.1, 136.5, 134.5, 130.7, 129.5 (2C), $129.2(2 \mathrm{C}), 125.4,123.3,119.0,118.7$ (d, $J=17.6 \mathrm{~Hz})$, $110.3,103.4(\mathrm{~d}, J=20.5 \mathrm{~Hz})$.

HR-LC MS: $m / z[\mathrm{M}+\mathrm{H}]^{+}$calcd for $\mathrm{C}_{18} \mathrm{H}_{12} \mathrm{ClF}_{2} \mathrm{~N}_{4}{ }^{+}$: 357.07131; found: 357.07132 .

\section{$\mathrm{N}$-(3,4-Difluorophenyl)-2-phenylimidazo[1,2-a]pyrazin-3-amine}

(10)

The corresponding sulfate salt was obtained as a mustard-yellow solid.

Yield: $0.91 \mathrm{~g}$ (95\%).

${ }^{1} \mathrm{H}$ NMR (400 MHz, DMSO + $\left.\mathrm{D}_{2} \mathrm{O}\right): \delta=9.32(\mathrm{~d}, J=1.3 \mathrm{~Hz}, 1 \mathrm{H}), 8.29$ (dd, $J=5.0,1.3 \mathrm{~Hz}, 1 \mathrm{H}), 8.03(\mathrm{~d}, J=5.0 \mathrm{~Hz}, 1 \mathrm{H}), 7.95(\mathrm{~d}, J=8.3 \mathrm{~Hz}, 2 \mathrm{H})$,), 7.39-7.45 (m, $3 \mathrm{H}), 7.16(\mathrm{dt}, J=10.3,9.0 \mathrm{~Hz}, 1 \mathrm{H}), 6.56-6.62(\mathrm{~m}, 1 \mathrm{H})$, $6.38-6.40(\mathrm{~m}, 1 \mathrm{H})$.

${ }^{13} \mathrm{C}$ NMR (100 MHz, DMSO): $\delta=150.5$ (dd, $J=244.3,13.9 \mathrm{~Hz}$ ), 143.8 (dd, $J=237.0,12.5 \mathrm{~Hz}), 141.8$ (d, $J=9.5 \mathrm{~Hz}), 141.7(\mathrm{~d}, J=8.1 \mathrm{~Hz})$, 139.5, 136.2, 131.3, 130.0, 129.5 (2C), 127.6 (2C), 125.5, 123.4, 119.0, $118.7(\mathrm{~d}, J=17.6 \mathrm{~Hz}), 110.4,103.3(\mathrm{~d}, J=21.3 \mathrm{~Hz})$.

HR-LC MS: $m / z[\mathrm{M}+\mathrm{H}]^{+}$calcd for $\mathrm{C}_{18} \mathrm{H}_{13} \mathrm{~F}_{2} \mathrm{~N}_{4}{ }^{+}$: 323.11028; found: 323.11030 .

\section{$N$-(3,4-Difluorophenyl)-2-(4-methylphenyl)imidazo[1,2-a]pyra- zin-3-amine (1p)}

The corresponding sulfate salt was obtained as a mustard-yellow solid.

Yield: $0.99 \mathrm{~g}(84 \%)$.

${ }^{1} \mathrm{H}$ NMR (400 MHz, DMSO + $\left.\mathrm{D}_{2} \mathrm{O}\right): \delta=9.33(\mathrm{~d}, J=1.0 \mathrm{~Hz}, 1 \mathrm{H}), 8.31$ (dd, $J=4.9,1.1 \mathrm{~Hz}, 1 \mathrm{H}), 8.05(\mathrm{~d}, J=5.0 \mathrm{~Hz}, 1 \mathrm{H}), 7.85(\mathrm{~d}, J=8 \mathrm{~Hz}, 2 \mathrm{H}), 7.25$ (d, $J=8.0 \mathrm{~Hz}, 2 \mathrm{H}$ ), 7.19-7.12 (m, $1 \mathrm{H},), 6.62-6.57$ (m, $1 \mathrm{H}$ ), 6.38-6.40 (m, $1 \mathrm{H}), 2.28(\mathrm{~s}, 3 \mathrm{H})$.

${ }^{13} \mathrm{C}$ NMR (100 MHz, DMSO): $\delta=150.1$ (dd, $J=243.6,13.4 \mathrm{~Hz}$ ), 143.5 $(\mathrm{dd}, J=236.5,12.9 \mathrm{~Hz}), 141.4,141.2(\mathrm{~d}, J=8.5 \mathrm{~Hz}), 139.9,138.9,135.9$, 130.1 (2C), 128.2, 127.5 (2C), 125.5, 123.2, 119.0, 118.7 (d, $J=18.3 \mathrm{~Hz}$ ), 110.4, 103.4 (d, $J=20.6 \mathrm{~Hz}), 21.4$.

HR-LC MS: $m / z[\mathrm{M}+\mathrm{H}]^{+}$calcd for $\mathrm{C}_{19} \mathrm{H}_{15} \mathrm{~F}_{2} \mathrm{~N}_{4}{ }^{+}$: 337.12593; found: 337.12604.

$N$-(3,4-Difluorophenyl)-2-(4-methoxylphenyl)imidazo[1,2-a]pyrazin-3-amine (1q)

The corresponding sulfate salt was obtained as a mustard-yellow solid.

Yield: $1.01 \mathrm{~g}(82 \%)$.

${ }^{1} \mathrm{H} \mathrm{NMR}\left(400 \mathrm{MHz}\right.$, DMSO $\left.+\mathrm{D}_{2} \mathrm{O}\right): \delta=9.34(\mathrm{~d}, J=1.0 \mathrm{~Hz}, 1 \mathrm{H}), 8.31$ (dd, $J=5.0,1.3 \mathrm{~Hz}, 1 \mathrm{H}), 8.06(\mathrm{~d}, J=5.0 \mathrm{~Hz}, 1 \mathrm{H}), 7.94(\mathrm{~d}, J=9.1 \mathrm{~Hz}, 2 \mathrm{H})$, $7.19(\mathrm{dt}, J=10.3,9.1 \mathrm{~Hz}, 1 \mathrm{H}), 7.02(\mathrm{~d}, J=9.1 \mathrm{~Hz}, 2 \mathrm{H}), 6.59-6.64(\mathrm{~m}$, $1 \mathrm{H}), 6.40-6.42(\mathrm{~m}, 1 \mathrm{H}), 3.76(\mathrm{~s}, 3 \mathrm{H})$.

${ }^{13} \mathrm{C}$ NMR (100 MHz, DMSO): $\delta=160.8,150.5(\mathrm{dd}, J=243.5,13.2 \mathrm{~Hz}$ ), 143.8 (dd, $J=236.3,13.2 \mathrm{~Hz}$ ), 141.8 (br, 2C), 138.6, 135.9, 129.1 (2C), 125.7, 123.3, 122.6, 118.8, 118.7 (d, $J=19.0 \mathrm{~Hz}), 115.0$ (2C), 110.3, $103.3(\mathrm{~d}, J=21.3 \mathrm{~Hz}), 55.8$.

HR-LC MS: $m / z[\mathrm{M}+\mathrm{H}]^{+}$calcd for $\mathrm{C}_{19} \mathrm{H}_{15} \mathrm{~F}_{2} \mathrm{~N}_{4} \mathrm{O}^{+}: 353.12084$; found: 353.12097.

$N$-(3,4-Difluorophenyl)-5-methyl-2-phenylimidazo[1,2-a]pyridin3-amine (7)

2-Amino-6-methylpyridine was used instead of 2-aminopyrazine.

Purification of the crude material was conducted differently. The crude material was suspended in TBME and stirred at r.t. for a few hours. The suspension was then cool to $0{ }^{\circ} \mathrm{C}$ and filtered off. The solid was washed with TBME and $\mathbf{7}$ was obtained as a white solid.

Yield: $1.01 \mathrm{~g}(67 \%)$. 
${ }^{1} \mathrm{H}$ NMR (400 MHz, DMSO): $\delta=8.31(\mathrm{~s}, 1 \mathrm{H}), 8.01(\mathrm{~d}, J=8.5 \mathrm{~Hz}, 2 \mathrm{H})$, 7.48 (d, $J=9.0 \mathrm{~Hz}, 1 \mathrm{H}), 7.38(\mathrm{t}, J=7.8 \mathrm{~Hz}, 2 \mathrm{H}), 7.13-7.31(\mathrm{~m}, 3 \mathrm{H})$, $6.66(\mathrm{~d}, J=6.8 \mathrm{~Hz}, 1 \mathrm{H}), 6.43($ br s, $1 \mathrm{H}), 6.19$ (br s, $1 \mathrm{H}), 2.65(\mathrm{~s}, 3 \mathrm{H})$.

${ }^{13} \mathrm{C}$ NMR (100 MHz, DMSO): $\delta=150.7$ (dd, $\left.J=243.5,13.9 \mathrm{~Hz}\right), 146.0$ (dd, $J=8.5 \mathrm{~Hz}), 143.9,142.9$ (dd, $J=234.2,13.1 \mathrm{~Hz}), 139.3,136.5$, 133.6, 128.9 (2C), 128.2, 127.1 (2C), 126.4, 119.6, 118.8 (d, $J=17.7 \mathrm{~Hz}), 115.6,114.2,108.8,101.8(\mathrm{~d}, J=20.0 \mathrm{~Hz}), 18.8$.

${ }^{19} \mathrm{~F}$ NMR (377 MHz, DMSO): $\delta=-137.1$ (d, $J=23.2 \mathrm{~Hz}$ ), -152.6 (d, $J=23.0 \mathrm{~Hz}$ ).

HR-LC MS: $m / z[\mathrm{M}+\mathrm{H}]^{+}$calcd for $\mathrm{C}_{20} \mathrm{H}_{16} \mathrm{~F}_{2} \mathrm{~N}_{3}{ }^{+}$: 336.1312; found: 336.1310 .

\section{Acknowledgment}

The skilful work and support of our technical staff (J. Keusch, F. Navarro) is gratefully acknowledged. We thank C. Guenat for measuring the HR-LC/MS spectra and the structure elucidation group of NIBR for their generous support and help.

\section{Supporting Information}

Supporting information for this article is available online at http://dx.doi.org/10.1055/s-0036-1588130.

\section{References}

(1) New address: E. Durantie, Adolphe Merkle Institute, BioNanomaterial, Chemin des Verdiers 4, 1700 Fribourg, Switzerland.

(2) Groebke, K.; Weber, L.; Mehlin, F. Synlett 1998, 661.

(3) Blackburn, C.; Guan, B.; Fleming, P.; Shiosaki, K.; Tsai, S. Tetrahedron Lett. 1998, 39, 3635.

(4) Bienaymé, H.; Bouzid, K. Angew. Chem. Int. Ed. 1998, 37, 2234.

(5) (a) Zhang, W.; Lu, Y.; Scott, P. J. H. In Solid-Phase Organic Syntheses; Scott, P. J. H., Ed.; John Wiley \& Sons, Inc: Hoboken, 2012, 51-57. (b) Ramesha, A. B.; Raghavendra, G. M.; Nandeesh, K. N.; Rangappa, K. S.; Mantelingu, K. Tetrahedron Lett. 2013, 54, 95. (c) Guchhait, S. K.; Chaudhary, V.; Madaan, C. Org. Biomol. Chem. 2012, 10, 9271. (d) Shukla, N. M.; Salunke, D. B.; Yoo, E.; Mutz, C. A.; Balakrishna, R.; David, S. A. Bioorg. Med. Chem. 2012, 20, 5850. (e) Hieke, M.; Rödl, C. B.; Wisniewska, J. M.; laBuscató, E.; Stark, H.; Schubert-Zsilavecz, M.; Steinhilber, D.; Hofmann, B.; Proschak, E. Bioorg. Med. Chem. Lett. 2012, 22, 1969. (f) Tyagi, V.; Khan, S.; Bajpai, V.; Gauniyal, H. M.; Kumar, B.; Chauhan, P. M. S. J. Org. Chem. 2012, 77, 1414. (g) Baviskar, A. T.; Madaan, C.; Preet, R.; Mohapatra, P.; Jain, V.; Agarwal, A.; Guchhait, S. K.; Kundu, C. N.; Banerjee, U. C.; Bharatam, P. V.J. Med. Chem. 2011, 54, 5013. (h) Burchak, O. N.; Mugherli, L.; Ostuni, M.; Lacapère,
J. J.; Balakirev, M. Y. J. Am. Chem. Soc. 2011, 133, 10058. (i) Guasconi, M.; Lu, X.; Massarotti, A.; Caldarelli, A.; Ciraolo, E.; Tron, G. C.; Hirsch, E.; Sorba, G.; Pirali, T. Org. Biomol. Chem. 2011, 9, 4144. (j) Akritopoulou-Zanze, I.; Wakefield, B. D.; Gasiecki, A.; Kalvin, D.; Johnson, E. F.; Kovar, P.; Djuric, S. W. Bioorg. Med. Chem. Lett. 2011, 21, 1480. (k) Buckmelter, A. J.; Ren, L.; Laird, E. R.; Rast, B.; Miknis, G.; Wenglowsky, S.; Schlachter, S.; Welch, M.; Tarlton, E.; Grina, J.; Lyssikatos, J.; Brandhuber, B. J.; Morales, T.; Randolph, N.; Vigers, G.; Martinson, M.; Callejo, M. Bioorg. Med. Chem. Lett. 2011, 21, 1248. (l) Guchhait, S. K.; Madaan, C. Org. Biomol. Chem. 2010, 8 , 3631. (m) Al-Tel, T. H.; Al-Qawasmeh, R. A.; Voelter, W. Eur. J. Org. Chem. 2010, 5586. (n) Guchhait, S.; Madaan, C. Synlett 2009, 628. (o) Krasavin, M.; Tsirulnikov, S.; Nikulnikov, M.; Sandulenko, Y.; Bukhryakov, K. Tetrahedron Lett. 2008, 49, 7318. (p) Kercher, T.; Rao, C.; Bencsik, J. R.; Josey, J. A. J. Comb. Chem. 2007, 9, 1177. (q) Shaabani, A.; Soleimani, E.; Maleki, A. Monatsh. Chem. 2007, 138, 73. (r) Masquelin, T.; Bui, H.; Brickley, B.; Stephenson, G.; Schwerkoske, J.; Hulme, C. Tetrahedron Lett. 2006, 47, 2989. (s) Parchinsky, V. Z.; Shuvalova, O.; Ushakova, O.; Kravchenko, D. V.; Krasavin, M. Tetrahedron Lett. 2006, 47, 947. (t) Lu, Y.; Zhang, W. QSAR Comb. Sci. 2004, 23, 827. (u) Ireland, S. M.; Tye, H.; Whittaker, M. Tetrahedron Lett. 2003, 44, 4369. (v) Blackburn, C.; Guan, B. Tetrahedron Lett. 2000, 41, 1495. (w) Varma, R. S.; Kumar, D. Tetrahedron Lett. 1999, 40, 7665.

(6) (a) Nagle, A.; Wu, T.; Kuhen, K.; Gagaring, K.; Borboa, R.; Francek, C.; Chen, Z.; Plouffe, D.; Lin, X.; Caldwell, C.; Ek, J.; Skolnik, S.; Liu, F.; Wang, J.; Chang, J.; Li, C.; Liu, B.; Hollenbeck, T.; Tuntland, T.; Isbell, J.; Chuan, T.; Alper, P. B.; Fischli, C.; Brun, R.; Lakshminarayana, S. B.; Rottmann, M.; Diagana, T. T.; Winzeler, E. A.; Glynne, R.; Tully, D. C.; Chatterjee, A. K. J. Med. Chem. 2012, 55, 4244. (b) Wu, T.; Nagle, A.; Kuhen, K.; Gagaring, K.; Borboa, R.; Francek, C.; Chen, Z.; Plouffe, D.; Goh, A.; Lakshminarayana, S. B.; Wu, J.; Ang, H. Q.; Zeng, P.; Kang, M. L.; Tan, W.; Tan, M.; Ye, N.; Lin, X.; Caldwell, C.; Ek, J.; Skolnik, S.; Liu, F.; Wang, J.; Chang, J.; Li, C.; Hollenbeck, T.; Tuntland, T.; Isbell, J.; Fischli, C.; Brun, R.; Rottmann, M.; Dartois, V.; Keller, T.; Diagana, T.; Winzeler, E.; Glynne, R.; Tully, D. C.; Chatterjee, A. K. J. Med. Chem. 2011, 54, 5116.

(7) Adib, M.; Mahdavi, M.; Noghani, M. A.; Mirzaei, P. Tetrahedron Lett. 2007, 48, 7263.

(8) Dömling, A.; Ugi, I. Angew. Chem. Int. Ed. 2000, 39, 3168.

(9) Chan, A. K.-W.; Wong, K. M.-C.; Yam, V. W.-W. J. Am. Chem. Soc. 2015, 137, 6920.

(10) Zakrzewski, J.; Huras, B.; Kiełczewska, A. Synthesis 2016, 48, 85.

(11) Lygin, A. V.; de Meijere, A. Org. Lett. 2009, 11, 389.

(12) Polisar, J. G.; Norton, J. R. Tetrahedron 2012, 68, 10236.

(13) Wang, J.; Rosingana, M.; Discordia, R. P.; Soundararajan, N.; Polniaszek, R. Synlett 2001, 1485. 